\title{
Deconstructing the meanings of and motivations for return: an Afghan case study
}

\author{
Marieke Van Houte ${ }^{1 *}$, Melissa Siegel ${ }^{2}$ and Tine Davids ${ }^{3}$
}

\author{
* Correspondence: \\ marieke.vanhoute@qeh.ox.ac.uk \\ ${ }^{1}$ International Migration Institute, \\ Department of International \\ Development, University of Oxford, \\ 3 Mansfield Road, Oxford OX1 3TB, \\ UK \\ Full list of author information is \\ available at the end of the article
}

\begin{abstract}
Return migration after conflict is the result of a complex decision-making process. However, our understanding of this complexity is blurred by changing politicized understandings of return. In this paper, we compare the autobiographical narratives of return of 'early' and 'late' (post-mid-1990s) arrivals of Afghans who met with changing reception regimes in Europe and returned to Kabul under a wide range of circumstances. We first develop a framework that attempts to understand migration from an actor-based rather than a bureaucratic perspective. We then deconstruct how Afghan migrants made sense of their own return migration, and analyse the ambivalences and seeming contradictions we find in them. The findings show that there are no clear-cut boundaries between voluntary and involuntary return decisions: almost no decision to return was entirely free, as there were legal constraints, family pressure, economic needs or socio-cultural difficulties at the basis of this decision. Almost no return decision was entirely forced, either, as most people did have the choice not to return, however harsh the alternative to returning would have been. At the same time, the analysis shows a strong empirical watershed between the post-return experiences of returnees who continue to have the capacity to be transnationally mobile and the experiences of those who do not. Concluding, we propose to centralize agency over mobility, facilitated by legal status and other factors, in the analysis of return. Concluding, the findings challenge the current policy-oriented binary categories. Alternatively, we propose to centralize the level of agency in decisions of transnational mobility as a more relevant factor in the analysis of return.
\end{abstract}

Keywords: Afghanistan, Return migration, Decision-making, Involuntary immobility, Mobility

\section{Introduction}

Return migration after conflict is the result of a complex decision-making process that may take place under very different levels of choice. However, our understanding of this complexity is blurred by politicized understandings of return. The end of the Cold War marked a change of discourse with regard to migrants arriving in Western European countries from conflict areas. Once accepting refugees from rival regimes had lost its ideological or geopolitical value (Chimni, 2000), immigration policies changed from protection and integration to containment and return (Black \& Gent, 2006; Koser \& Black, 1999). In 
European migration management policies, return of unwanted migrants, such as asylum seekers whose claim was rejected or expired after a conflict has ended, therefore became a priority since the 1990s (Hammond, 1999; Omata, 2013; Stein \& Cuny, 1994).

In the current policy focus on return, managing voluntary return is considered as less costly and politically less painful than enforced removal (Blitz, Sales, \& Marzano, 2005; Ottonelli \& Torresi, 2013; Stein \& Cuny, 1994). But when a (post-)conflict country is declared safe to return to and temporary asylum statuses expire, European host states usually plan for 'voluntary' return, with financial inducements or the threat of deportation, much sooner than these migrants themselves. In policy-driven categorizations, the notion of voluntariness has furthermore become based on the use of physical force, and any non-deported return is considered as 'voluntary' (see Chimni, 2000; Ottonelli \& Torresi, 2013).

Such broad notions of 'voluntary' return contain a wide variety in legal and administrative circumstances of return. The policy-driven categorization of 'voluntary' return has therefore lost much of its logical meaning. For example, the International Organization for Migration (IOM) distinguishes between non-mandatory and mandatory voluntary return (Beltman, 2012). These categorizations obscure the understanding of the realities of return, such as why 'voluntary' returnees want to reemigrate after return (Schuster \& Majidi, 2013), and why people have to be held in detention to prevent them escaping their 'voluntary' return. A better understanding of return could inform more adequate policy responses to both meet the needs of returnees and host and origin states (Castles, 2007).

In addition to policy, research has also insufficiently addressed the complexity of return migration, for two main reasons. First, policy-oriented research often follows bureaucratic definitions for pragmatic reasons of being able to communicate with policy makers. But by following these narrowly oriented frameworks, researchers limit themselves in their ability to fully understand the meanings of return (Hammond, 1999). Second, migration research has historically made a clear distinction between forced and voluntary migration. Research on forced migration from conflict-affected countries has focused on the structural forces determining migration. This is reinforced by activists for migrants' rights who highlight that these forced migrants need protection and assistance (Ottonelli \& Torresi, 2013). However, such politicized understandings do not reflect the complexity of reasons to migrate, which are often a combination between security, economic, political and social reasons (King, 2012; Koser \& Black, 1999; Ottonelli \& Torresi, 2013) and 'assume away the agency of migrants' by seeing them as victims rather than purposeful actors (Bakewell, 2008). In contrast, several authors argue that even when taking place under immediate threats to security, mobility involves both choices and constraints, which blurs the conceptual boundaries between voluntary and involuntary mobility (Bakewell, 2008; Hyndman, 2012; King, 2012; Lubkemann, 2008; Monsutti, 2008; Stein \& Cuny, 1994). Still, the notion of the level of choice over return is relevant as research shows that the motivation for return has a strong influence on reintegration and wellbeing after return. The challenge for empirical research is then to develop analytical tools to obtain more adequate understandings of the meanings and motivations of return (Al-Ali, Black, \& Koser, 2001; Bakewell, 2010; Carling, 2002; Cassarino, 2004; Castles, 2007; Omata, 2013). 
In this paper, we compare the autobiographical narratives of Afghans return migrants, defined as migrants who travel back to their country of birth to live there, regardless of the circumstances and motivation to do so and regardless of length of stay. Comparing a wide range of migration trajectories of migrants who were confronted with changing circumstances in both country of origin and country of arrival, and who returned under different circumstances, from being deported to complying with Assisted Voluntary Return (AVR) whilst having the legal obligation to leave, to returning while having the legal opportunity to stay, we deconstruct how these different returnees discuss their own decisions to return and their experiences after return, and analyse the ambivalences and seeming contradictions we find in them. Analysing this wide variety of return motivations allows an understanding of return beyond policy-oriented dichotomies of voluntary and involuntary return. This is particularly relevant in a time where Europe is again facing increased inflows of conflict-generated migrants that reach the levels of the mid-1990s. Although return is considered as the most durable solution for refugees, learning from past experiences would help to nuance this view in order to deal with upcoming issues of migration and return in a more sustainable way.

In the remainder of this paper, we first introduce a framework that attempts to understand migration from an actor-based rather than a bureaucratic perspective. The framework recognizes mobility, including return migration, as a process that takes place under different and changing structural circumstances, with different capacities and desires, creating different levels of agency over mobility (Bakewell, 2010; Cassarino, 2004; Castles, 2007). We then discuss the methodology, highlighting that the narratives are illustrative of the variety, rather than a representative sample of the population of return migrants. We then analyse these narratives to show how different levels of agency to return emerge, and how they interact with subtexts of mobility and security. Based on our findings, we challenge the current policy-oriented categories of voluntary and involuntary return and we propose to centralize mobility in the analysis of return.

\section{Analytical framework and building blocks}

Roughly, two types of theoretical discussions have tried to address the dynamics of (return) migration: the duality between structure and agency on the one hand, and the links between desires, or aspirations, and capacity, abilities and capabilities on the other. We use a comprehensive analytical framework, presented in Fig. 1, to connect both theoretical discussions. This framework sees human behaviour, including migration and transnational engagement, as the result of the interaction between individuals' agency, desires and capacities, which are in interaction with the structural environment. When studying return migration, the framework can show how the decision to return can take place under different levels of agency. Below, we will briefly elaborate on each of the analytical building blocks of this framework and their interrelations while referring to a separate paper (Van Houte, 2016) for a more thorough discussion of this framework.

Structures can be defined as forces that are external to and have an impact on people, such as institutional, economic, social and cultural systems (Giddens, 1984, in Sewell, 1992) that can be at macro, meso and micro levels (Castles, 2007; Sewell, 1992); both in places of origin and destination. Institutional structures that may affect migration 


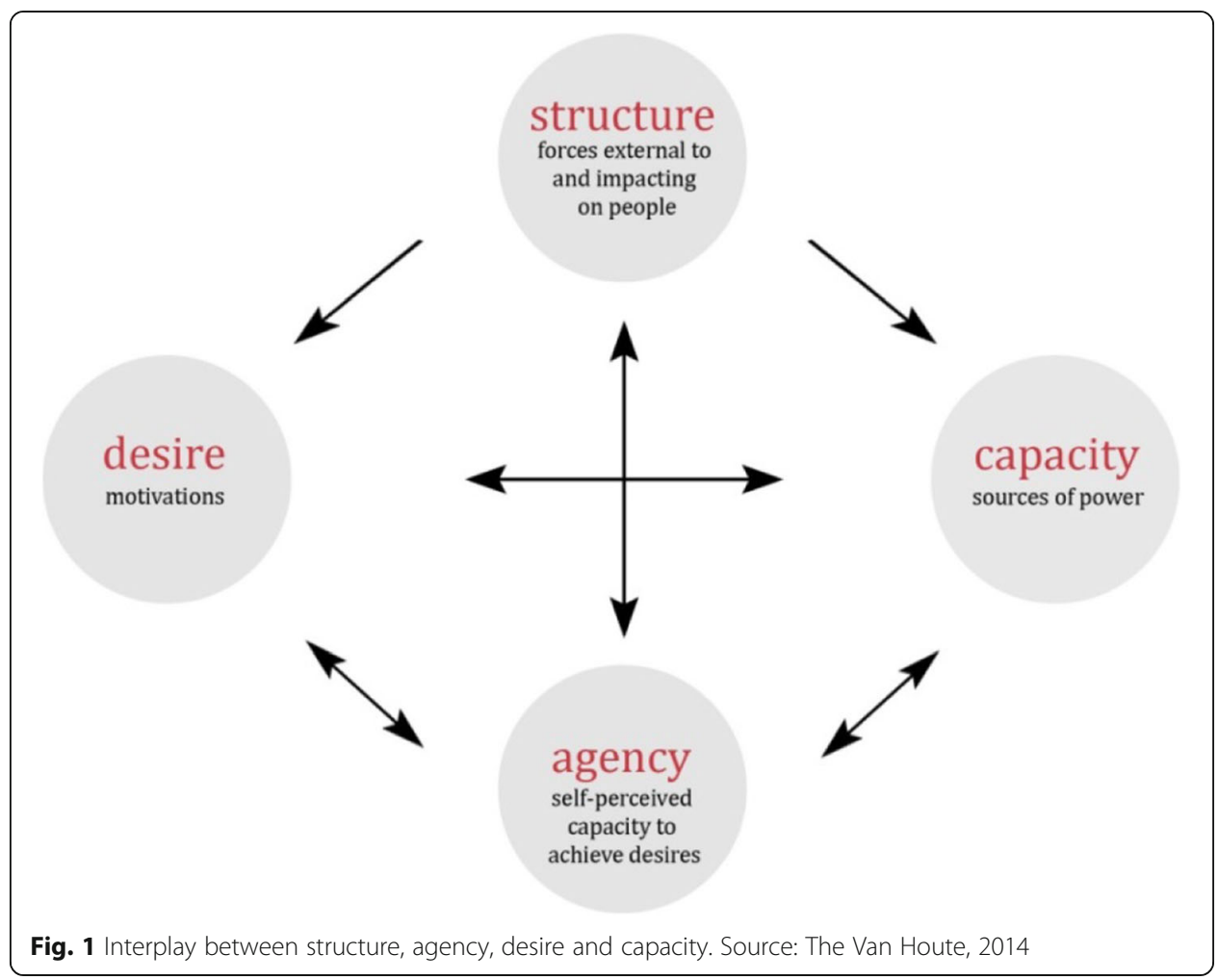

decisions include political ideologies, international relations and migration policies (Carling, 2002). Examples of relevant economic structures are wealth and inequality levels and employment opportunities versus the cost of migration (Carling, 2002; Cassarino, 2004; De Haas, 2010). Social structures can be how migration is perceived in society, social pressure to migrate, but also other social structures such as patterns of discrimination and gender norms (Carling, 2002). Cultural structures may be norms, values and traditions, that lead to a certain migration ethos (Carling, 2002).

Agency captures the notion that human action is not just determined by structures, but that humans have a certain degree of choice and control over their social relations and actions within these structures (Hitlin \& Elder, 2007; Sewell, 1992). Agency does not necessarily equal action: It is about the self-reflective beliefs we have about our abilities and capacities (our self-efficacy) to act, which is analytically separate from our actual acts. Self-efficacy is argued to be the central aspect of agency, since actors who perceive themselves as having agency are more likely to persevere in the face of problems, and develop a sense of personal empowerment (Hitlin \& Elder, 2007). Translated to migration, agency to be mobile can therefore both result in movement and in non-movement of people (De Haas, 2014; Jensen, 2011). Structures do not only define the boundaries of agency, but they are also shaped by it (Giddens, 1984 as cited in King, 2012; Sewell, 1992). In this way, structures not only constrain, but also enable action (Sewell, 1992).

Desires and capacities and similar concepts capture the analytical distinction between what people want to do and what they are able to do. Al-Ali et al. (2001) introduce the distinction between actors' capacities or abilities, and their desires or willingness to engage in transnational activities. While Al Ali et al. look at transnational activities in 
general, Carling (2002) and De Haas (2010) have developed models to analyse mobility and migration. Carling's model distinguishes between people's aspiration to migrate and their ability to do so. He stresses that the observation that all mobility involves both choices and constraints can incorporate the analysis of migration and nonmigration, including involuntary immobility (Carling, 2002). Similarly, De Haas sees people's propensity to migrate as a function of aspirations and abilities (De Haas, 2010). Finally, Cassarino developed a model specifically for return, distinguishing between willingness and readiness, which together create the preparedness to return. Cassarino's model takes into account the fact that return is not necessarily a voluntary act and it can incorporate the analysis of a wide variety of migrants, including economic, skilled, unskilled and forced migrants. The model therefore enables an analysis of return that goes beyond dichotomies of success and failure of return (Cassarino, 2004).

More than the abstract concepts of agency and structure, these models of desire and capacity provide concrete tools for a nuanced empirical analysis on different experiences of transnationalism, mobility and return. These models can compare migrants' capacities with their desires to explain their behaviour and experience. Capacities and desires can take place on all dimensions of life: the institutional dimension may include legal status, freedom of movement and documentation; desires and capacities on the economic dimension include employment, education, career, skills, savings, economic independence, experience and physical strength; the social dimension may comprise networks, social obligations, and social status and equality; and a cultural dimension can include taste, creativity, inclusion, dignity, freedom of expression and risk aversiveness (Al-Ali et al., 2001; Carling, 2002; Cassarino, 2004; Emirbayer \& Mische, 1998; Sewell, 1992). These models of desires and capacities have enriched the understanding of the complex dynamics of migration in the interplay and negotiation between multiple capacities and multiple desires.

Our analytical framework places models of desires and capacities as intermediate factors between models of structure and agency, in order to enable an actor-oriented analysis that goes beyond the individual migrant's experience. In this framework, structures affect both an individual's capacities, which we define as human and non-human resources that can serve as a source of power for the actor) and their desires, which we define as intentions or motivations to act, which are in turn interrelated. Agency, which we define as an actor's self-perception of the capacity to achieve their desires, is determined by these desires and capacities, and is both shaped by and shapes structure.

Below, we will first discuss how we collected the narratives on which our analysis is based. After giving a general account of the relevant structural realities in which Afghan returnees from European host countries were embedded, we will then discuss how the different dimensions of the framework discussed above interrelate in narratives of return.

\section{Methodology}

The fieldwork for this article was conducted by the Van Houte in cooperation with an Afghan translator in Kabul between May and July 2012 during two field visits of 1 month each. The capital Kabul as a research site reflected the reality of return: approximately $30 \%$ of all returnees settled in Kabul (Stigter, 2006). In addition, Afghans who 
migrated to Europe were more likely to be of urban background and were more likely to return to Kabul (Stigter, 2006; Turton \& Marsden, 2002).

The participants in the study included 35 Afghan returnees, who had returned mainly from the Netherlands, the United Kingdom, Germany and Scandinavia. The sensitive subject of return and the security constraints made random sampling difficult. Returnees were therefore contacted through as many as possible entry points: first, based on a list of the participants of earlier research, second, through networking via several entrance points in Kabul and third, through snowball sampling, which is a suitable sampling technique if a population is hidden (Bloch, 2008).

The core of this study consisted of the collection of life histories of returnees, an indepth approach that helped to provide a holistic understanding of the meanings that returnees ascribe to their migration and return experience and helps to go past the over-generalized notions of migration and return that we wanted to overcome (Eastmond, 2007; Findlay \& Li, 1997). When telling their life history, people usually present their narrative as having a meaningful and coherent order, marked by key happenings, which can show how they frame and ascribe meaning to their experiences from the perspective of today (Eastmond, 2007). The narratives provided insight in how the respondents lived through or adapted to changes (Lutz, 1998) and brought to the surface heterogeneity, ambiguity and contradictions in their stories.

This autobiographical exercise was complemented with creative participatory techniques, mainly time line drawing, where participants were asked to draw a summary of their life in a timeline, and to then reflect on and construct their own understandings of the themes that are discussed (Pain \& Francis, 2003). Such ways of expression can make it easier to discuss issues that would not be possible to discuss in verbal interviews, for example when they are too controversial or sensitive to talk about (Bagnoli, 2009). Elsewhere, we talk in more detail about the added value of such techniques in migration research (Van Houte, forthcoming). It was attempted to have at least two individual meetings with all respondents. In addition to the individual interviews and meetings, three group discussions were held with the returnees and key informants were consulted.

Life histories and narratives are creative constructions of the past, generated in specific contexts of the present and in relation to the audience (Eastmond, 2007; Gibbs, 2007). A number of contextual and relational factors are expected to have affected the construction of the narratives of return. First, the urban focus of the study means that the narratives are not representative for more remote or rural areas. Second, the majority of the respondents were male, which reflects a demographic reality of return but nevertheless puts a strong male bias on the narratives. The gender dimension is also likely to have caused variation in the relationally constructed narratives, as some interviews were directly conducted by the female interviewer, while others were carried out with the help of male translators. Third, some narratives were told in face-to-face conversations, while others were told in group meetings. Although there is no way to control for the influence of these relational factors, we provide information about the original language used, whether the narrative was given through a translator and whether it was expressed during an interview or in a group meeting.

A fourth aspect that may have affected the narratives of return is the vulnerable position of a portion of the research group. For some respondents, telling their life story was negatively associated with interrogations during the asylum procedures, 
leading to more reluctance in telling their story. For others, meeting a European researcher became a potential survival strategy in which they emphasized their unfortunate situation, hoping to access some form of support. By contrast, a need to find a sense of dignity or pride in a vulnerable situation may have led respondents to emphasize the successful and positive sides of their story. By creating a safe atmosphere and by following rather than leading the respondents in their narratives, while clearly stating the interviewer's position as an independent researcher, and reinforcing that their participation in the study would not affect their personal lives positively or negatively, it was attempted to minimize these biases. Nevertheless, no interview takes place in a social vacuum, and any analysis of these narratives needs to take into account this subjectivity. The texts that were obtained with life histories and group discussions were coded and analysed with the help of computer assisted qualitative data analysis software, Atlas.ti. After giving a general account of the structures in which Afghan migrants were embedded, we will discuss how structures, desires, capacities and agency interrelated in narratives of return.

\section{Structural reality of Afghan conflict and migration}

The structural reality in which migration from and return to Afghanistan took place, has significantly changed over more than 35 years of Afghan conflicts. The subsequent conflicts caused different 'waves' of migration, each with their own reasons to migrate and their own demographical characteristics. In addition, Afghan migrants met changing political structures in their host countries, making it a relevant case that shows the changes in the political discourse over the last three decades from protection to return (Jazayery, 2002; Monsutti, 2008; Stigter, 2006).

In 1979, the Soviet Union invaded Afghanistan to support the Afghan communist regime (Collins, 2011), sparking a first wave of outmigration of Afghans who fled in reaction to the detentions and executions of non-leftist intellectuals (Jazayery, 2002). In 1992, 3 years after the Soviet Union had withdrawn, the Afghan communist regime was overthrown by the Mujahedeen. These early phases of the conflict caused an outflow of refugees from the Afghan élite who were affiliated with the pre-communist or communist regime and feared reprisals. Those with the greatest resources were able to travel directly to the United States or Europe. As long as Afghanistan was a central stage in the Cold War, these Afghan early arrivals in industrialized countries were often given refugee status and eventually citizenship (Oeppen, 2009).

After seizing power, the several ethnic factions of the Mujahedeen fell apart in civil war. The escalation of violence led to new movements of refugees escaping generalized and ethnic violence as the fighting moved across Afghanistan. The refugee population exceeded six million people in the early 1990s (Jazayery, 2002; Oeppen, 2009). The continued civil conflict was the breeding ground for the rise of the Taliban in 1994, who took control over Kabul in 1996 (Collins, 2011). The violent conquest of the country and the harsh regime imposed by the Taliban, the ethnic cleansing of the Hazara population who were being persecuted for their Shi'a background, and the prolonged drought between 1998 and 2001, caused another outflow of Afghans (Collins, 2011; Jazayery, 2002; Turton \& Marsden, 2002). By the year 2000, there were again six million Afghan refugees (Turton \& Marsden, 2002). 
Following the changing political discourse after the end of the Cold War, the international community started to scale down their schemes to protect refugees in the neighbouring countries and shifted their attention towards repatriation (Blitz et al., 2005; Collins, 2011; Turton \& Marsden, 2002). Many Afghans who did not want to return, and who had the opportunity, migrated onwards to Europe (Turton \& Marsden, 2002). However, Afghans who arrived in European countries during and after the second half of the 1990s also encountered increasingly restricted immigration and asylum policies (Hyndman, 2012).

After Al Qaeda attacked several targets in the United States on 11 September 2001, and the refusal of the Taliban to extradite Al Qaeda's leader Osama bin Laden, the United States launched their 'War on Terror' against Al Qaeda and the Taliban. The fighting and bombings in Afghanistan again resulted in an outflow of Afghans, including those associated with the Taliban regime (Jazayery, 2002; Oeppen, 2009).

After the overthrow of the Taliban, the largest repatriation operation of refugees in the UNHCR's history took place from 2002 onwards. However, several authors note that return 'home' to Afghanistan was not evident (Blitz et al., 2005; Jazayery, 2002; Monsutti, 2008): The discrepancy between the idealized country of origin and the reality of the war-torn society made return a difficult decision (Al-Ali et al., 2001; Jazayery, 2002). In particular for migrants who went further afield and ended up in Europe, the financial, physical and emotional investments made when migrating mean that they had a lot to lose by going back (Zimmermann, 2012).

Nevertheless, Afghans did return from Europe after 2002, under various conditions. First, the greater ability to travel to Afghanistan led to a growing number of Afghans with permanent residence status who were willing to return to invest in and contribute to the reconstruction of the country (Jazayery, 2002). While most of them returned temporarily to work in the reconstruction, interpreting and consultancy sectors and to sell or rent family properties, a small proportion of these returnees stayed in Afghanistan for a longer term (Blitz et al., 2005; Oeppen, 2009). Second, after the events of 11 September 2001, a general rise in xenophobia led to stricter migration policies (Hyndman, 2012; Koser \& Black, 1999). European states withdrew temporary asylum statuses, became stricter on incoming asylum seekers and initiated the return of Afghans without permanent legal statuses in 'voluntary' return programmes (Schuster, 2011).

The structural reality of Afghan migration has shifted considerably over time, changing the demographic constitution of migrants, the migration management policies they dealt with and the underlying international relations that played a role. Therefore, early arrivals were more likely to receive legal status in the country of destination than late arrivals. This in turn became a an important factor in the shaping of migrants' experience of return, which will be discussed below (Al-Ali et al., 2001; Bloch, 2008).

\section{Narratives of return}

Why did Afghans return from Europe? This section compares the narratives of the decision to return by 'early' and 'late' arrivals to European countries, to explore how changing structural conditions affected the interaction between capacity, desire 
and agency. This collection of narratives shows the widest possible variety of this interaction, rather than claiming to be a representative sample of the population of return migrants.

\section{Early arrival}

Early arrivals of Afghans to European countries consisted mainly of people of middle or upper class background, who left the country after the fall of the communist regime and the civil war in the late 1980s and early 1990s, and travelled directly to Western Europe. All early arrivals in this sample were given refugee status and now held citizenship of their destination country. Within this enabling structural reality of a relatively open regime towards refugees and access to legal status, the respondents in this group returned under different combinations of desires and capacities.

Besharat came with his parents to the Netherlands in the Netherlands in 1992, when he was 15 years old. As a political refugee and later citizen of the country, he had every formal opportunity to participate in society. But when he had to choose his education and professional development, he felt his ambitions were held back by his immigrant background. He said that people told him to settle for a modest education, and that his creative career aspirations were discouraged.

[In the Netherlands] if I told someone I wanted to be [an artist], they said are you crazy, that is so expensive. (...) He said there is no job for you there. Then my dream again went back to the ground.

- Besharat (m, interview, original in English).

Although there were no formal barriers to pursuing an artistic career, Besharat's experienced a normative force in society that kept his ambitions at a low level. His narrative is typical of Afghans of a higher socio-economic background who had high career ambitions but experienced a glass ceiling in the host country, which they related to discrimination and racism (see Ammassari, 2004). Besharat had a strong desire to become an artist, but he felt that his capacity to break through this stigma of being a foreigner was limited. During a visit to Afghanistan, he was offered a more attractive job and he stayed. From there he quickly grew to become a successful artist.

And when I know I come back, I feel for the first time that I am out of the gevangenis (jail). (...) All the opportunity you have there (in the Netherlands), everything can be done, security, hospital, beveiliging (security). (...) Here is you have nothing, but still for me, if I was in Holland, (...), I'm sitting in a jail.

- Besharat.

Besharat described his return to Afghanistan as a liberation from a constraining environment, that enabled him to realize his artistic dreams. By stressing that Afghanistan 
is a lot less organized and safe than the Netherlands, he highlighted his determination and the offers he is willing to make to realize his career ambitions.

Eshan, unlike Besharat, did not mention a social-economic glass ceiling. He also migrated along with his parents to Germany, obtained refugee status and German citizenship. Having left at an earlier age of 7 years old, he received a large part of his education there and found a job that matched his level of education. Still, after some years of working in Germany, he applied for a job in Afghanistan and returned. He explained:

After I finished my studies and all this time I worked, and I was quite bored about everything. And didn't know why (...) I'm not happy because I had everything (...). And then what was still something missing and I was looking for it what can it be, should I change my job, should I change my style, should I change my life, and what's the problem. (...) And then I found out, maybe it's a good thing to go back to my roots and start again as a human being (...) can you live in Afghanistan, it is something for you, do you still identify yourself as an Afghan?

- Eshan (m, interview, original in English).

Eshan's narrative shows that although he had every capacity to lead an economically prosperous life, he also felt he lacked a sense of meaning and belonging in his life, which made him feel depressed. He tells the story of his return as part of a personal desire to reinvent himself, and finding a new sense of identity and happiness.

Tareq, who had Dutch citizenship, a good job and a Dutch wife, said he was perfectly happy with his life in the Netherlands, which changed after the events of 9/11.

It started when my mother-in-law, she was a bit... How should I put it (laughs) she didn't like foreigners. She didn't like them. And after that the case of 11 September. Made it worse. So she tried everything to separate us. And she did it.

- Tareq (m, interview, original in Dutch).

Tareq highlighted that the increased discrimination towards Afghans, foreigners and Muslims after 9/11 caused his mother-in-law to turn against him and enforce a divorce from his wife. He was not able to keep his family together. In the juridical aftermath of the divorce, Tareq also lost custody over his children, which he related to the legal system being focused on mothers' rights and neglecting those of the father. As a father, a husband, and Afghan and a Muslim, he felt he had lost all sense of control over the situation, which put so much stress on him that he started to develop psychosomatic problems such as a loss of function in his legs. On an impulse, he decided to go back to Afghanistan.

I never thought I would come back here. Suddenly I had the thought. You know what, I'll go, see what happens there. 
After facing sudden social and legal exclusion from his family, Tareq returned to Afghanistan and remarried to an Afghan woman. His story of return strongly driven by a desire to be back in charge of his family life. He said he had teared up his Dutch passport and would never set foot in the Netherlands again. However, as the security situation in Afghanistan started deteriorating, he was now thinking of moving again, together with his wife.

The stories of early arrivals such as Besharat, Eshan and Tareq show that their agency to decide to stay or move can be seen as an effort to match desires and capacities on different dimensions of life. Their decisions of return can be both a reaction to constraints and a sense of opportunity for a different life. These constraints and opportunities mainly concerned the soico-economic dimension in the case of Besharat, a cultural and psychological dimension in the case of Eshan, and a social and institutional dimension in the case of Tareq.

\section{Late arrivals}

The stories of later arrivals, after the mid-1990s, were very different from the early arrivals, as they were characterized by people who were of more modest background. Many of these people had initially migrated to neighbouring countries and moved on after being pushed out, or after years of travelling. When they arrived in Europe, the attitude to asylum seekers and return had changed: none of the late arrivals in the sample had received a permanent legal status of the host country. Instead, they had either received a temporary protection, which expired after the fall of the Taliban, or they were rejected as asylum seekers. Both categories meant that they were legally obliged to return. Within this more constrained structural reality of a more unwelcoming asylum regime and limited access to legal status, the respondents in this group returned under different combinations of desires and capacities. While some returnees in this group returned through so-called Assisted Voluntary Return programmes, others, who refused to comply with AVR and stayed as undocumented migrants, were eventually arrested and deported.

The most negative account of return under these circumstances comes from Wasim. ${ }^{1}$ After Wasim left Afghanistan, both because of the conflict in the country and a conflict in his own family, it took him about 8 years to reach the United Kingdom, where he arrived in 2000. He did not manage to obtain refugee status, but he was determined not to return to Afghanistan. He said that he brought a knife with him each time he had to report to the police, with the intention of committing suicide if he was going to be deported. But when that day came, he said, he did not have his knife with him. Instead, he physically resisted his deportation so strongly that his arm was broken in the struggle. The interview took place 5 years after his return to Afghanistan from the UK. When asked how he was doing, he started crying and explained how his life had been miserable since his return. He said that because he was illiterate and had received no education, his only economic opportunity was to do manual labour, which the lasting effects of his broken arm had made impossible.

The lack of prospects for a life in Afghanistan and the large financial and temporal investment he had made to reach Europe, gave Wasim a strong desire to stay in the UK (see also Zimmermann, 2012). However, as he did not have the legal capacity to 
stay, his capacity to prevent his return was limited to physical resistance: he fought with the police when he was deported. The agency he had over his return decision was minimal, as his alternatives were extreme: instead of being deported to Afghanistan, he could have gone into hiding from the police. After he was arrested, death by suicide was his only alternative to returning to Afghanistan. Confronted with his extremely limited choices, his strong desire to stay, the lack of capacity to do so, and the sudden and enforced conditions of deportation made his return a disempowering experience. Wasim displayed his broken arm as a symbol of how his return continued to affect his life negatively. Other Afghans who were deported told narratives with a similar, resentful tone.

The story of Areef shows a returnee with a different narrative in a similar structural reality. Areef left Afghanistan at the age of 16, with the intention to find a means to support his family, who were in a deprived situation because of the war. He travelled for 2 years before he reached the Netherlands. He applied for asylum three times and lived in the Netherlands for 10 years, with four of these years being spent as an undocumented migrant under difficult circumstances. Although he tried everything to stay, at some point he decided to return by signing up for AVR. He said:

How long do you want to stay in the Netherlands? You will never get a permanent status. Here, every time I call here, my mother says you have to go back, my father says 'come back'. And I heard my father died. Only then I say 'OK, I go back to Afghanistan'.

- Areef (m, interview, original in Dutch).

Like Wasim, Areef lived as an undocumented migrant, and he had no legal capacity to stay in the Netherlands. He could only rely on some support by NGOs, which did enable him to survive in the Netherlands. But his desire was not so much his own survival, but to be able to support his family, which comes forward from a responsibility to succeed in the task of migrating as a household strategy. By linking his return decision to the repeated requests from his family and the death of his father, he describes his return as the best option to meet the desire to effectively support his family within his capacities.

Hamid, who returned through AVR, is a good example of the complexity of return motivations. Below are quotes from an interview with him, in chronological order, which represent a seemingly contradictory narrative.

I was not rejected. I could stay there. But my father was sick and I stay very long time there. And I (was) supposed to come to help my father, to service to my father in the last time of his life and to get his prayer for my life. (...)

Then when the Taliban collapsed, the Holland government sent some people to me, saying that now the Taliban is not a threat. So you are more than welcome to go back to your country. And they took my passport, they took everything else. And I said $\mathrm{OK}$ and I waited waited waited and it continued for about 2.5 years. (...)

If there's any chance, you can take [my passport] to Holland and if you can renew it, bring it back here and I can go, that would be great.(...) 
Actually it would have been a lot better if I was accepted in Holland but unluckily I could not get the chance. I just missed it somehow. And my friends are still there and they're having a good time. But the thing is that I really like Afghanistan and Afghanistan is a best place for me. I have my family here. I have my relatives, and to be honest, I cannot compare a little dust of Afghanistan, a very unpaved street of Afghanistan to a very beautiful place in Holland. Because this country this is my mother. (...)

And when I came, I had some money in my pocket that I brought from Holland. And when I came I saw my dad he was really in a terrible situation as he was sick and plus they were renting a house and they didn't pay rent of the house for 4 months, they were behind for 4 months. (...)

And then everybody encouraged me for taking care of my dad and everybody persuaded me and said now you see you're the older son of your dad and now he sees you here, and now he's no longer sick, so... And I was really happy for that.

- Hamid ( $m$, interview, original in Dari, via translator).

When he returned, Hamid's temporary ID had already been withdrawn, and he knew that it would be hard to stay in the Netherlands for much longer without the legal capacity to do so. On the one hand, his failure to stay in the Netherlands was very disappointing and disempowering to him ('they took my passport, they took everything else'), especially since he felt a relative failure compared to his friends. On the other hand, he claimed agency over his return by stressing that he returned even though he did not have to (yet), because he was needed by his family. To match his limited capacities, Hamid highlighted the desire to be in his 'mother' country and to support his parents, in order to claim agency over his return.

When their legal capacity to stay in the host country had been restricted, several returnees stressed that a desire to reunite with their country, their family, and their culture, had been the reason to return. However, if returnees like Hamid had wanted to return, why did he and many other returnees try to open up the possibility of leaving again, in the case of Hamid by asking the researcher to reissue his 'passport'? Several returnees themselves also observed this contradiction:

Those people who are saying that they are really happy being in Afghanistan, and they don't wanna go back. Believe it or not if you gave them their passport and their visa, if their departure is at ten, I'm sure they want to leave at nine.

- Kamal (m, interview, original in Dari, via translator).

The story of Ajmal provides some insights. Like Hamid, he insisted that he had himself decided to return, while it also became clear that he was a rejected asylum seeker and was legally obliged to do so. Although he would have liked to build up his life in the Netherlands, he did not have the capacity to find employment within the structural reality of his status as an asylum seeker, which made him feel as if he was wasting his time. After he returned through AVR, he rebuilt a successful business and was able to 
renovate his house in central Kabul. In this way, he claimed agency over his return by matching his desires and his capacities. However, he also said:

I am happy for my life, I love my country, I love my Afghanistan, my kids, I am here. But in case if there is any problem in the future, we don't know the future, what will happen. If there's something the Holland government could do to help us. Just ideas.

- Ajmal ( $m$, interview, original in Dari, via translator).

Reza, who was deported from the UK, also became a rather successful businessman after return. Reza explained that with his own construction company he could make more money in Afghanistan than when doing unskilled work in the UK. Nevertheless, he said that he had tried many times to leave Afghanistan again. One time he paid a human smuggler to bring his family to Canada, but he was deceived and lost his money. He said:

So many times I try to go back there. (...) Actually, I don't know why I want to go there. (laughs). Back.

- Reza (m, interview, original in English).

The return decision of late arrivals such as Wasim, Areef, Hamid, Kamal and Ajmal, too, could be seen as an effort to match desires with capacities, although within a framework of more limited choice compared to early arrivals. The changed structural reality had strongly affected their legal capacity to stay, which severely limited the agency over their decision to return. But beyond having determined their return decision in the past, their legal status continued to determine agency in mobility decisions in the present. From the structural reality of Afghanistan's unstable political situation and insecure future, an underlying desire for security and mobility emerged. Having lost their capital on the previous failed migration experience, and facing increasing restricted migration policies and thus riskier and more expensive travel routes, decreased their capacities to migrate out of Afghanistan. This inability to match desires and capacities, resulting in a lack of agency over their post-return mobility, caused a lot of unrest and discontent among these returnees, giving them the feeling that they were 'stuck' in a highly explosive environment. These returnees' involuntary immobility (Carling, 2002) added a subtext that gave their narratives the seemingly contradictory twists.

\section{Discussion and conclusion: deconstructing the meanings of and motivations for return}

In this paper, we have deconstructed return as a complex decision-making process, while avoiding generic conclusions that return 'is very complex', or providing deterministic understandings that predict the outcome of migration. We showed the interaction between structures, capacities, desires and agency, in which all elements reinforce each other in a continuous process that may lead to seemingly contradictory narratives. Agency can be seen as an actor's effort to match their desires and capacities, while being shaped by, and shaping, the structural context. 
In this mechanism, all actors can display a degree of agency over their actions, either through enhancing their capacities to meet their desires, or by redefining their desires to match their capacities.

The analysis of this case study of Afghan return migrants centred around the structural reality of changing migration policies and their impact on desires and capacities to return. Migrants who had the capacity to leave early arrived in Europe at a time when the structural reality of migration discourses worked to their advantage. They received permanent status to stay in the host country. Their decision to return was made to match their desires and capacities on the economic, social or cultural dimension. By contrast, people who left later arrived at a time when the structural reality of the migration discourse was less advantageous. Consequently, their legal capacity in the host country restricted their possibility of staying there. As a reaction, many returnees highlighted their desires of being with their family, and their culture as a justification for return.

The narratives show that almost no decision to return was entirely free, as there were legal constraints, family pressure, economic needs or socio-cultural difficulties at the basis of this decision. Almost no return decision was entirely forced, either, as most people did have the choice not to return, however harsh the alternative to returning would have been. Both early arrivals like Eshan, Besharat and Tareq and late arrivals like Wasim, Areef, Hamid, Ajmal and Reza tended to claim as much agency over their return as they could, showing how important it is for people to have control of their decisions. Still, we see a gradual scale, depending on social, economic, institutional and cultural capacities and desires, interacting with structures and leading to different levels of agency over the decision to return.

These findings therefore show that there are no clear-cut boundaries between voluntary and involuntary return decisions (see also Monsutti, 2008). What the analysis does show, however, is a strong empirical watershed between the post-return experiences of returnees who still have the capacity to be transnationally mobile and the experiences of those who do not. Practically, legal status of the host country caused this watershed in the different narratives of return. The permanent legal status in the host country of early arrivals allowed them to be transnationally mobile, which meant that they had returned while knowing that they would be able to re-emigrate if necessary. Transnational mobility gave these returnees a sense of security and comfort in the highly unstable context of Afghanistan, which proved to be of essential importance in the mind-sets of people, and affected every aspect of life. By contrast, for returnees who did not have a legal residence status in the former host country the only option to leave Afghanistan was to re-emigrate clandestinely, which was increasingly risky and costly (Blitz et al., 2005). As most lacked the funds and support from relatives to do so, they experienced involuntary immobility (Carling, 2002). This caused a lot of unrest and discontent, and a feeling that they were 'stuck' in a potentially explosive environment.

Concluding, the findings challenge the current policy-oriented binary categories based on the use of force, in which all non-deported return is considered voluntary. The wide variety of narratives shows the inadequacy of this categorization. As an alternative to the use of force as an analytical boundary, we propose to centralize the level of agency in decisions of transnational mobility, facilitated by legal status and other factors, both pre- and post- return, as a more relevant factor in the analysis of return. Beyond the case study of Afghan return, this article showed that the narrative as a research methodology proved 
essential in unravelling this complexity and providing an empirically grounded alternative to the policy-oriented categorizations. Moreover, the framework that was used has the potential to be used to study migration in any context and in changing circumstances.

\section{Endnote}

${ }^{1}$ To protect the privacy of the participants in this study, all names are pseudonyms. For the same reason, details such as towns or countries of residence are sometimes intentionally unspecified.

\section{Abbreviations}

NGO: Non-governmental organization; UK: United Kingdom; UNHCR: United Nations High Commissioner for Refugees

\section{Authors' contributions}

MVH was responsible for the conception and design of the study, the collection and analysis of data,and drafting of the manuscript; MS and TD were involved in critically revising the manuscript for intellectualcontent throughout the writing process. All authors read and approved the final manuscript.

\section{Competing interests}

The authors declare that they have no competing interests.

\section{Authors' information}

$\mathrm{MvH}$ is a Marie Curie Postdoctoral Research Fellow at the International Migration Institute, Department of International Development at the University of Oxford.

MS is Professor of Migration Studies at the Maastricht Graduate School of Governance | UNU-MERIT at Maastricht University.

TD is a lecturer at the Department of Anthropology and Development Studies and the Centre for International Development Issues Nijmegen (CIDIN) at Radboud University Nijmegen.

\section{Author details}

${ }^{1}$ International Migration Institute, Department of International Development, University of Oxford, 3 Mansfield Road, Oxford OX1 3TB, UK. ${ }^{2}$ Maastricht Graduate School of Governance| UNU-MERIT, P.O. Box 616, 6200 MD Maastricht, The Netherlands. ${ }^{3}$ Department of Anthropology and Development Studies, Centre for International Development Issues Nijmegen (CIDIN), Radboud University, PO Box 9104, 6500 HE Nijmegen, The Netherlands.

Received: 27 February 2016 Accepted: 16 November 2016

Published online: 07 December 2016

\section{References}

Al-Ali, N., Black, R., \& Koser, K. (2001). Refugees and transnationalism: The experience of Bosnians and Eritreans in Europe. Journal of Ethnic and Migration Studies, 27(4), 615-634.

Ammassari, S. (2004). From nation-building to entrepreneurship: The impact of élite return migrants in Côte d'Ivoire and Ghana. Population, Space and Place, 10(2), 133-154. doi:10.1002/psp.319

Bagnoli, A. (2009). "Beyond the Standard Interview: The Use of Graphic Elicitation and Arts-based Methods." Qualitative Research 9(5): 547-570.

Bakewell, O. (2008). 'Keeping them in their place': The ambivalent relationship between development and migration in Africa. Third World Quarterly, 29(7), 1341-1358. doi:10.1080/01436590802386492

Bakewell, O. (2010). Some reflections on structure and agency in migration theory. Journal of Ethnic and Migration Studies, 36(10), 1689-1708. doi:10.1080/1369183x.2010.489382

Beltman, D. (2012). Voluntary return facilities for aliens without residence permits in comparative perspective. In G. J. Vonk (Ed.), Cross border welfare state. Immigration, social security and integration. Antwerpen: Intersentia.

Black, R., \& Gent, S. (2006). Sustainable return in post-conflict contexts. International Migration, 44(3), 15-38. doi:10.1111/j.1468-2435.2006.00370.x

Blitz, B. K., Sales, R., \& Marzano, L. (2005). Non-voluntary return? The politics of return to Afghanistan. Political Studies, 53(1), 182-200. doi:10.1111/j.1467-9248.2005.00523.x

Bloch, A. (2008). Zimbabweans in Britain: Transnational activities and capabilities. Journal of Ethnic and Migration Studies, 34(2), 287-305.

Carling, J. (2002). Migration in the age of involuntary immobility: Theoretical reflections and Cape Verdean experiences. Journal of Ethnic and Migration Studies, 28(1), 5-42. doi:10.1080/13691830120103912

Cassarino, J.P. (2004). Theorising return migration: The conceptual approach to return migrants revisited. International Journal on Multicultural Societies (IJMS), 6(2), 253-279.

Castles, S. (2007). Twenty-first-century migration as a challenge to sociology. Journal of Ethnic and Migration Studies, 33(3), 351-371. doi:10.1080/13691830701234491

Chimni, B. S. (2000). Globalization, humanitarianism and the erosion of refugee protection. Journal of Refugee Studies, 13(3), 243-263. doi:10.1093/jrs/13.3.243

Collins, J. J. (2011). Understanding war in Afghanistan. Washington: National Defence University Press.

De Haas, H. (2010). Migration and development: A theoretical perspective. International Migration Review, 44(1), 227-264. doi:10.1111/j.1747-7379.2009.00804.x 
De Haas, H. (2014). Migration theory: Quo Vadis. IMI Working Papers (100)

Eastmond, M. (2007). Stories as lived experience: Narratives in forced migration research. Journal of Refugee Studies, 20(2), 248-264. doi:10.1093/jrs/fem007

Emirbayer, M., \& Mische, A. (1998). What is agency? American Journal of Sociology, 103(4), 962-1023. doi:10.1086/231294

Findlay, A. M., \& Li, F. L. N. (1997). An auto-biographical approach to understanding migration: The case of Hong Kong emigrants. Area, 29(1), 34-44. doi:10.1111/j.1475-4762.1997.tb00005.x

Gibbs, G. R. (2007). Analyzing Qualitative Data. Los Angeles, Sage.

Hammond, L. (1999). Examining the discourse of repatriation: Towards a more proactive theory of return migration. In R. Black \& K. Koser (Eds.), The end of the refugee cycle? Refugee repatriation and reconstruction (pp. 227-244). New York/Oxford: Berghahn.

Hitlin, S., \& Elder, G. H. (2007). Time, self, and the curiously abstract concept of agency. Sociological Theory, 25(2), 170-191. doi:10.1111/j.1467-9558.2007.00303.x

Hyndman, J. (2012). The geopolitics of migration and mobility. Geopolitics, 17(2), 243-255. doi:10.1080/ 14650045.2011 .569321

Jazayery, L. (2002). The migration-development nexus: Afghanistan case study. International Migration, 40(5), 231-254. doi:10.1111/1468-2435.00218

Jensen, A. (2011). Mobility, space and power: On the multiplicities of seeing mobility. Mobilities, 6(2), 255-271. doi:10.1080/17450101.2011.552903

King, R. (2012). Geography and migration studies: Retrospect and prospect. Population, Space and Place, 18(2), 134-153. doi:10.1002/psp.685

Koser, K., \& Black, R. (1999). The end of the refugee cycle? In R. Black \& K. Koser (Eds.), The end of the refugee cylce? Refugee repatriation and reconstruction (pp. 2-17). New York/Oxford: Berghahn Books.

Lubkemann, S. C. (2008). Involuntary immobility: On a theoretical invisibility in forced migration studies. Journal of Refugee Studies, 21(4), 454-475. doi:10.1093/jrs/fen043

Lutz, H. (1998). The legacy of migration: Immigrant mothers and daughters and the process of intergenerational transmission. In M. Chamberlain (Ed.), Caribbean migration. Globalised identities (pp. 96-110). London: Routledge.

Monsutti, A. (2008). Afghan migratory strategies and the three solutions to the refugee problem. Refugee Survey Quarterly, 27(1), 58-73. doi:10.1093/rsq/hdn007

Oeppen, C. (2009). A stranger at home: Integration, transnationalism and the Afghan Elite. (PhD Thesis), University of Sussex, Sussex

Omata, N. (2013). The complexity of refugees' return decision-making in a protracted exile: Beyond the home-coming model and durable solutions. Journal of Ethnic and Migration Studies, 39(8), 1281-1297. doi:10.1080/1369183X.2013.778149

Ottonelli, V., \& Torresi, T. (2013). When is migration voluntary? International Migration Review, 47(4), 783-813. doi:10.1111/imre.12048

Pain, R. and P. Francis (2003). "Reflections on Participatory Research." Area 35(1): 46-54.

Schuster, L. (2011). Turning refugees into 'illegal migrants': Afghan asylum seekers in Europe. Ethnic and Racial Studies, 34(8), 1392-1407. doi:10.1080/01419870.2010.535550

Schuster, L., \& Majidi, N. (2013). What happens post-deportation? The experience of deported Afghans. Migration Studies, 1(2), 221-240. doi:10.1093/migration/mns011

Sewell, W. H., Jr. (1992). A theory of structure: Duality, agency, and transformation. American Journal of Sociology, 98(1), 1-29. doi:10.2307/2781191

Stein, B. N., \& Cuny, F. C. (1994). Refugee repatriation during conflict: Protection and post-return assistance. Development in Practice, 4(3), 173-187. doi:10.1080/096145249100077811

Stigter, E. (2006). Afghan migratory strategies - an assesment of repatriation and sustainable return in response to the convention plus. Refugee Survey Quarterly, 25(2), 109-122. doi:10.1093/rsq/hdi0129

Turton, D. and P. Marsden (2002). Taking Refugees for a Ride? The Politics of Refugee Return to Afghanistan. Issues Paper Series. Islamabad, The Afghanistan Research and Evaluation Unit (AREU).

Van Houte, M. (2014). Moving Back or Moving Forward? Return Migration After Conflict. Maastricht, Maastricht University. PhD Thesis.

Van Houte, M. (2016). Transnational Transformations: Coupling Migration and Change. IMI Working Paper Series. $130,1-23$.

Zimmermann, S. (2012). Understanding repatriation: Refugee perspectives on the importance of safety, reintegration, and hope. Population, Space and Place, 18(1), 45-57. doi:10.1002/psp.647

\section{Submit your manuscript to a SpringerOpen ${ }^{\circ}$ journal and benefit from:}

- Convenient online submission

- Rigorous peer review

- Immediate publication on acceptance

- Open access: articles freely available online

- High visibility within the field

- Retaining the copyright to your article

Submit your next manuscript at $\boldsymbol{s p r i n g e r o p e n . c o m ~}$ 